\title{
Speciation of iron, nickel and cobalt in the anaerobic biodegradation of rice straw
}

\author{
Especiación de hierro, níquel y cobalto en la biodegradación anaerobia de la paja de arroz
}

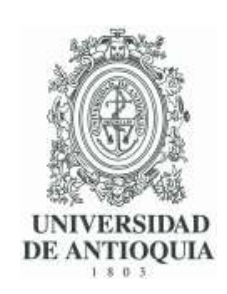

\author{
Aimeé González-Suárez (D) ${ }^{1}$, Ileana Pereda-Reyes (D) ${ }^{*}$, Deny Oliva-Merencio (D)2, Silvio Jacinto \\ Montalvo-Martínez (iD ${ }^{3}$ \\ ${ }^{1}$ Centro de Estudios de Ingeniería de Procesos (CIPRO), Universidad Tecnológica de La Habana "José Antonio Echeverría" \\ (Cujae). 11901, 114 Street, Marianao. C. P. 19390. La Habana, Cuba. \\ ${ }^{2}$ Centro de Estudios de Tecnologías Energéticas Renovables (CETER), Universidad Tecnológica de La Habana “José \\ Antonio Echeverría" (Cujae). 11901, 114 Street, Marianao. C. P. 19390. La Habana, Cuba. \\ ${ }^{3}$ Laboratorio de Biotecnología Ambiental, Universidad de Santiago de Chile. Av Libertador Bernardo 0'Higgins 3363 , \\ Santiago, Estación Central, Región Metropolitana. C. P. 71783-5. Santiago, Chile.
}

\section{CITE THIS ARTICLE AS:}

A. González, I. Pereda, D. Oliva and S. J. Montalvo. "Speciation of iron, nickel and cobalt in the anaerobic biodegradation of rice straw", Revista Facultad de Ingeniería Universidad de Antioquia, no. 101, pp. 55-63, Oct-Dec 2021. [Online].

Available: https :

//www.doi.org/10.17533/

udea.redin. 20200366

\section{ARTICLE INFO:}

Received: January 30, 2019

Accepted: June 05, 2020

Available online: June 05, 2020

\section{KEYWORDS:}

Biogas; metals; mineral; productivity; waste treatment

Biogás; metales; mineral; rendimiento; tratamiento de residuos
ABSTRACT: The bioavailability of $\mathrm{Fe}, \mathrm{Ni}$ and $\mathrm{Co}$ and its impact on the mono-digestion of rice straw with addition of a natural nutrient source were assessed. The chemical forms and the degree of bioavailability of $\mathrm{Fe}, \mathrm{Ni}$ and $\mathrm{Co}$ were investigated in two reactors during 311 days of experimentation at $37^{\circ} \mathrm{C}$. The reactor (R2) was supplemented with $1 \mathrm{~g} / \mathrm{L}$ of mineral once a week. The control reactor R1 was limited in mineral during the study. The greatest methane yield of $238 \mathrm{~mL} / \mathrm{g}$ VS was obtained with mineral supply with an increment of $45 \%$ respect to reactor without metals $(164 \mathrm{~mL} / \mathrm{g}$ VS). The sequential extraction confirmed that 70,88 and $75 \%$ of $\mathrm{Fe}, \mathrm{Ni}$ and $\mathrm{Co}$ were mainly in bioavailable forms (interchangeable and carbonate), respectively, with mineral supply in R2. Fe and Co were mainly associated to the carbonate and oxidizable fractions $143 \%$ and $41 \%$ respectively), while the $\mathrm{Ni}$ concentrations were not detected during the experimentation. As a result, the methane yield in R2 increased by $45 \%$, with a potential bioavailability ( $\mathrm{Ni}>\mathrm{Co}>\mathrm{Fe}$ ) higher compared to control reactor ( $\mathrm{Co}>\mathrm{Fe})$. Trace elements deficit in $\mathrm{R} 1$ result in the reduction of metal-binding forms until the end of experiment, with a negative impact on methanogenic community.

RESUMEN: Se investigó la biodisponibilidad de Fe, Ni y Co y su impacto en la monodigestión de la paja de arroz con la adición de una fuente natural de nutrientes. La distribución de las formas de enlace de $\mathrm{Fe}$, Ni y Co y su potencial de biodisponibilidad se evaluó en dos reactores durante 311 días de experimentación a $37^{\circ} \mathrm{C}$. En el reactor R2 se suministró una dosis de mineral de $1 \mathrm{~g} \mathrm{~L}-1$ una vez por semana. El reactor control (R1) estuvo limitado de mineral durante el estudio. El mayor rendimiento de metano de $238 \mathrm{~mL} / \mathrm{g}$ SV se obtuvo con el suministro de mineral, con un incremento de $45 \%$ respecto al reactor sin metales $(164 \mathrm{~mL} / \mathrm{g}$ VS). La extracción secuencial confirmó que el $70 \%, 88 \%$ y $75 \%$ de $\mathrm{Fe}$, Ni y Co estuvieron principalmente en formas biodisponibles, intercambiables y carbonato, respectivamente, cuando se adicionó el mineral en R2. En R1, el Fe y Co estuvieron principalmente asociados a las fracciones de carbonatos y materia orgánica-sulfuro ( $43 \%$ y $41 \%$ ), respectivamente, siendo las concentraciones de Ni no detectadas durante la experimentación. Como resultado, el rendimiento de metano en R2 incrementó en un $45 \%$, con un potencial de biodisponibilidad ( $\mathrm{Ni}>$ Co $>$ Fel mayor en comparación con el reactor control ( $C_{0}>$ Fe). La limitación de metales en $\mathrm{R} 1$ condujo al agotamiento de las fracciones biodisponibles, con un impacto negativo en la comunidad metanogénica.

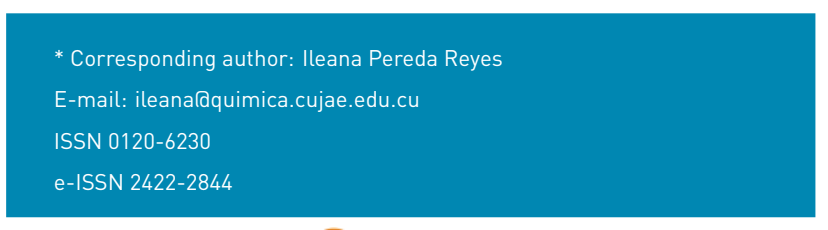




\section{Abbreviations}

$\begin{array}{ll}\text { OLR } & \text { organic loading rate } \\ \text { HRT } & \text { hydraulic retention time } \\ \text { SCSTR } & \begin{array}{l}\text { semicontinuous completely stirred tank } \\ \text { reactors }\end{array} \\ \text { SE } & \text { sequential extraction } \\ \text { TS } & \text { total solids } \\ \text { VS } & \text { volatile solids } \\ \text { BMP } & \text { biochemical methane potential } \\ \text { VFA } & \text { volatile fatty acid } \\ \text { VFA/TIC } & \text { volatile fatty acids/total inorganic carbon } \\ & \text { ratio }\end{array}$

\section{Introduction}

In recent years, lignocellulosic residues have been gaining much attention as biomass for producing bioenergy [1]. However, its anaerobic degradation has been mainly limited by the interactions of the components: lignin, cellulose, and hemicellulose, which create a recalcitrant structure to microbial attack [2]. Another disadvantage of the anaerobic degradation of this biomass is its trace elements shortage, i.e. Ni, Fe, Co, Se, Mo, and W. The trace metals are very important for the methanogenic process due to they are related to the structure of several enzymes and co-factors [3-5]. Therefore, the micronutrients addition is a prerequisite to stimulate the methanogens activity and to reach high organic loading rates (OLRs) [6].

Several investigations have been focused on the improvement of the lignocellulosic residues biodegradability by means of different pre-treatments [7-9]. Others studies have directed on the trace metals (salts) supply, using single trace metal or combinations, during anaerobic process of lignocellulosic material, e.g. agricultural waste, with the aim of maintaining the stability of anaerobic digestion $[10,11]$. These studies reported a stimulating effect on methane yield, in the ranging from 350 - $429 \mathrm{ml} \mathrm{CH}$ g/VS, with increases between 15-36\% compared to the substrates without trace metals addition.

Recent studies have demonstrated that the micronutrients addition from mineral source have a similar positive effect on different lignocellulosic substrates, such as microcrystalline cellulose [12] and maize straw [13]. The highest methane yields from mono-digestion of microcrystalline cellulose and maize were 397 and 257 $\mathrm{mlCH}_{4} / \mathrm{gVS}$, when mineral addition was $5 \mathrm{mg} / \mathrm{L}$ and 1 $\mathrm{g} / \mathrm{L}$, respectively. These doses increased the methane production by $31 \%$, compared to values obtained by the reactor mineral-limited. A micronutrients dosage strategy might be effective to improve the performance of anaerobic process of lignocellulosic materials.
Cuba has a natural mineral source with a varied composition of macro and micronutrients, that can be profitable to the process. However, to date, there are no reports on the use of minerals as a source of micronutrients in the mono-digestion of lignocellulosic biomass e.g rice straw. In addition, there is no assessment of the metal bonding forms during the operation of the reactor in semi-continuous regimen when the mineral is applied as a micronutrient. Research efforts are needed to utilize information on the speciation and bioavailability of trace elements to improve our understanding of their roles and requirements of trace metals in bioreactors, and to optimize trace element application strategies.

Therefore, the present study aims at evaluating the speciation and bioavailability of $\mathrm{Fe}, \mathrm{Ni}$ and $\mathrm{Co}$ and examining the effect on methane yield from rice straw anaerobic mono-digestion with mineral supply.

\section{Material and methods}

\subsection{Materials}

Rice straw was collected from an agricultural region of Nueva Paz, (Mayabeque province, Cuba). The rice straw was milled until a particle size of $0.5 \mathrm{~mm}$. It was stored in plastic bags at room temperature until further processed.

The inoculum was collected from a biodigester treating pig manure and organic solid waste (Experimental Station of Pastures and Forages "Indio Hatuey", Matanzas province) and prepared according to VDI 4630 [14]. Previous to the experiment, the reactor was operated with the organic loading rate (OLR) of $0.5 \mathrm{gVS} / \mathrm{L}$.d under mesophilic condition (37 $\pm 1{ }^{\circ} \mathrm{C}$ ). The inoculum adaptation was prolonged for five weeks and the process continued along two weeks in order to remove the residual biodegradable components. The inoculum filtered by a sieve of $3 \mathrm{~mm}$ was used to inoculate the reactors.

A natural mineral mixture with a particle size from 0.12-0.25 mm was provided by the Cuban Research Centre for the Mining and Metallurgical Industry (CIPIMM).

\subsection{Sampling procedures}

Sampling was carried out at the start-up of the experiment and after 260, 294 and 308 days of digestion. Before sampling, both reactors were previously stirred for 10 min. For determination of trace metals, samples were withdrawn using syringes and centrifuged at $10000 \mathrm{rpm}$ for $10 \mathrm{~min}$, and the supernatant was filtered through cellulose acetate membrane $(0.45 \mu \mathrm{m})$. The samples were kept at $4^{\circ} \mathrm{C}$ until use. 
Table 1 Steps undertaken during sequential extraction

\begin{tabular}{llll}
\hline \multirow{2}{*}{ Fraction } & \multirow{2}{*}{ Extracting agent } & \multicolumn{2}{c}{ Extraction conditions } \\
\cline { 3 - 4 } & & Shaking time ${ }^{\mathrm{a}}$ & Temperature $\left({ }^{\circ} \mathrm{C}\right)$ \\
\hline Exchangeable & $10 \mathrm{~mL} \mathrm{NH} \mathrm{CH}_{3} \mathrm{COO}(1 \mathrm{M}, \mathrm{pH}=7)$ & $1 \mathrm{~h}$ & 20 \\
Carbonate & $10 \mathrm{~mL} \mathrm{CH} \mathrm{CH}_{3} \mathrm{COOH}(1 \mathrm{M}, \mathrm{pH}=5.5)$ & $1 \mathrm{~h}$ & 20 \\
Oxidizable & $5 \mathrm{~mL} \mathrm{H} \mathrm{O}_{2}(30 \%, \mathrm{pH}=2)$ & $3 \mathrm{~h}$ & 35 \\
Residual & $10 \mathrm{~mL} \mathrm{Aqua} \mathrm{regia}\left(\mathrm{HCl} / \mathrm{HNO}_{3}, 3: 1\right)$ & $30 \mathrm{~min}$ & Microwave $120^{\circ} \mathrm{C}$ \\
\hline
\end{tabular}

${ }^{a}$ Shaking was applied at $100 \mathrm{rpm}$

\subsection{Process description}

Two $6 \mathrm{~L}$ rice straw-fed SCSTRs were conducted at $37 \pm$ $1{ }^{\circ} \mathrm{C}$ with a hydraulic retention time (HRT) of 30 days. The digesters were operated for about 311 days with the OLR of 0.5 to $3.0 \mathrm{gVS} / \mathrm{L} . \mathrm{d}$.

$\mathrm{R} 1$, as the control reactor, was fed without mineral addition and $1 \mathrm{~g} / \mathrm{L}$ of mineral once per week was supplemented to reactor R2 in different phases: with mineral supply (I and III) and without mineral supply (II). Mineral dosage was obtained from previous studies about the methane production from mono-digestion of lignocellulosic biomass (maize and rice straw) with different mineral dosage (10-1000 mg/L) (data not shown). Feeding was carried out once a day, and the methane volume was measured according to the liquid displacement method using a $\mathrm{NaOH}(15 \%)$ solution. The values of methane volumes were normalized according to VDI 4630 [14].

\subsection{Fe, Ni and Co concentration}

The total concentration of $\mathrm{Fe}, \mathrm{Ni}$ and $\mathrm{Co}$ in the sludge sample was extracted by aqua regia digestion according to [15]. The concentration was measured using atomic absorption spectrometry (AAS, 130B-WFX). All reagents were of analytical-reagent grade and the glassware was washed with $7 \mathrm{M} \mathrm{HNO}_{3}$ for at least $12 \mathrm{~h}$ prior to use.

\subsection{Sequential extractions (SE)}

The metal speciation analysis were assessed according to the method proposed by modified Tessier, as described by [16] (Table 1). The principle of this method is the use of different extraction solvents solubilizing specific fractions of metals. The defined fractions for the SE were sludge liquid phase, referred as: exchangeable (1), carbonates (2), oxidizable (3) and residual (4). Nevertheless, reducible fractions, e.g. metals bound to Fe oxides, are not extracted because their extraction tends to oxidize the anoxic samples and thus overestimates metals bound to oxidized compared to reduced compounds [16].

Extractions were performed in triplicate $11 \mathrm{~g}$ wet sludge, based on TS) and the $\mathrm{Fe}, \mathrm{Ni}$ and $\mathrm{Co}$ extracted after
SE-step was measured using AAS according to [15]. The result of the analytical determination is provided in $\mathrm{mg}$ $\mathrm{g}^{-1}$ TS. Moreover, the recovery rate of each element was calculated as the sum of the amounts in all single fractions related to the total content in the fresh sample. Details can be found in [15].

From the metal fractions distribution, the potential bioavailability was evaluated, taking into account the decreasing solubility/reactivity from the first to the last step. This decrease in solubility is used as a measure of potential bioavailability in bioreactors [17], where the first fraction is considered the most bioavailable, and the last fraction, the least bioavailable.

\subsection{Statistical analyses}

One-way analyses of variance (ANOVA) and Tukey's multi-comparison test were performed to evaluate the effect of mineral supplementation on the anaerobic digestion of rice straw and to compare mean methane yields between both reactors (R1 and R2) in each studied phase. The data analyses were performed using STATGRAPHICS Centurion XV.II.

\section{Results and discussion}

\subsection{Characterisation of feedstock, mineral and inoculum}

Chemical parameters including trace metals content of rice straw, mineral and inoculum were analysed at the beginning of the experiments (Table 2). Based on these results, Fe was found in low concentration in the feedstock, and it is clearly below the range $11-10 \mathrm{mg}$ $\mathrm{Fe} / \mathrm{L}$ ) of recommended concentrations by [18] in anaerobic digestion. Therefore, a deficiency of this metal can be assumed. Especially the elements $\mathrm{Ni}$ and $\mathrm{Co}$ were below the detection limit.

Low content of these metals, even their absence, is an aspect characteristic of this kind of biomass $[10,18,19]$. One of the key factors to enhance the anaerobic process is an appropriate supplement of micronutrients $[20,21]$. For 
that reason, the mineral addition is justified as a natural source for nutrient balance. On the contrary, all essential elements were found in the inoculum and mineral in higher extent.

Table 2 Characterisation of inoculum, feedstock and mineral used in the fermentation tests

\begin{tabular}{llll}
\hline \multirow{2}{*}{ Parameter } & \multicolumn{3}{c}{ Material } \\
\cline { 2 - 4 } & Inoculuma & Rice straw $^{\mathbf{a}}$ & Mineral \\
\hline $\mathrm{pH}$ & 7.6 & 6.5 \\
$\mathrm{TSb}$ & 59.7 & 890.8 & \\
$\mathrm{VSb}$ & 39.7 & 723.1 & n.a \\
VS (\%TS) & 67.0 & 89.0 & \\
Lignin (\%TS) & - & 8.6 \\
\multicolumn{5}{c}{} & Trace elements (mg/g TS) \\
$\mathrm{Fe}^{\mathrm{b}}$ & 0.615 & 0.049 & 296.17 \\
$\mathrm{Ni}^{\mathrm{b}}$ & 0.021 & $0.000^{*}$ & 3.56 \\
$\mathrm{Co}^{\mathrm{b}}$ & 0.011 & $0.000^{*}$ & 0.58
\end{tabular}

${ }^{a}$ Average duplicate samples
${ }^{b}$ Concentrations in $\mathrm{mg} / \mathrm{L}$ (inoculum) and $\mathrm{mg} / \mathrm{g}$ (rice straw)
n.a not analyzed
${ }^{*}$ Values below the limit of detection

\subsection{Effects of mineral supplementation on methane production from rice straw}

In order to investigate the effect of $\mathrm{Fe}, \mathrm{Ni}$ and $\mathrm{Co}$ addition on methane yield from rice straw degradation, the mineral was added to the reactor R2 at doses of $1 \mathrm{~g} / \mathrm{L}$ once a week. Table 3 presents the $\mathrm{CH}_{4}$ yields of both reactors and the increments respect to control test (R1) during the experimental phases.

R1 mineral-limited exhibited a stable process performance under conditions in Phases I and II in terms of methane yield (169-170 mL/gVS) and no significant differences were detected. However, after a long period of operation, a decrease in methane yield was observed (Phase 3), starting at day 268 with a drop up to $19 \%$, compared to Phase II (Table 3 and Figure 1). These results might be attributed to both, deficiency of trace elements in the reactor and their depletion along the process. Similarly, Pobeheim et al. [11], described that the limitation of $\mathrm{Ni}$ and Co during anaerobic digestion of a defined model substrate for maize decreased biogas production by about 10\%. Likewise, Demirel and Scherer et al. [22], reported that the unavailability of micronutrients might be the main reason causing the poor of the bioreactor.

Consequently, the initial trace elements concentrations in the inoculum allowed a stable process performance at the starting in R1. However, with the regular operation of the reactor, the metal concentrations were reduced gradually not being available for microbial uptake.
Metals shortage in anaerobic reactor decreases the enzymatic reactions of methanogenesis, which might result in the decreased methane yield [4]. It was observed that diminishing the OLR up to $2 \mathrm{~g} \mathrm{VS/L.d} \mathrm{enhanced}$ the $\mathrm{CH}_{4}$ yield in the last phase. Nevertheless, the values reached in $\mathrm{R} 1$ during the overall fermentation were relatively low (137-170 mL CH$/ \mathrm{gVS}$ ) compared to $\mathrm{CH}_{4}$ yield values (195-280 $\mathrm{mL} \mathrm{CH}_{4} / \mathrm{gVS}$ ) reported from mesophilic anaerobic digestion of rice straw analyzed in BMP test without trace elements supplementation [23-25]. These results confirmed previous findings that semi-continuous anaerobic digestion of lignocellulosic biomass without trace metals addition was not stable $[4,10,11]$.

The VFA/TIC ratio /volatile fatty acids/ total inorganic carbonate) and $\mathrm{pH}$ variations in both bioreactors during degradation of rice straw are illustrated in Figure 2. The results showed that the $\mathrm{pHs}$ values varied between 7.0 and 7.7 in the two reactors, which is in the required range of 6.6-7.8 for good development of methanogens [10]. The VFA/TIC ratios values were lower than 0.25 . This parameter is an indicator of process instability and stress and values above 1.0 have demonstrated to be inhibitory to anaerobic digestion [4].

On the other hand, with the mineral dosing strategy (1 $\mathrm{g} \mathrm{L}^{-1}$ once a week, phase I) applied to R2, a slightly higher yield significantly compared to R1 was observed (Table 3). The availability of metals in the reactor may meet the requirement of the methanogens, which results in the improvement of process. However, in order to induce a deficit of nutrients, and to evaluate with greater clarity the mineral effect on the methane yield, R2 was mineral-limited during 2 nd phase, maintaining the OLR (3 $\mathrm{g}$ VS/L.d). During the stop process of mineral supply from days 99 to 259, a stable behavior was observed, with an increase of $12 \%$ respect to the control reactor.

Afterwards, on day 260 (phase III), mineral supply was restarted in R2, and it was maintained until concluding the study (Figure 1). The mineral supply exhibited positive effects on methane yield in this reactor, reaching the highest value of methane yield of $238 \mathrm{~mL} \mathrm{CH} / \mathrm{g}$ VS with an increment of $45 \%$ respect to the rice straw biodegradation without mineral $(164 \mathrm{~mL} \mathrm{CH} / \mathrm{g}$ VS). The findings confirmed the synergistic effects of trace elements on methane production, which were consistent with the reported by [26]. It is well known that in the methanogenesis several metal-rich enzymes, which catalyze key metabolic steps, require sufficient supply of $\mathrm{Fe}, \mathrm{Ni}$ and $\mathrm{Co}_{0}$ [20]. This explains the high dependence of the methanogens on bioavailability of micronutrients [27].

Previous investigation described stimulatory effects 
Table 3 Methane yields obtained from rice straw biodegradation with and without mineral addition

\begin{tabular}{lllll}
\hline \multirow{2}{*}{ Operating phase } & \multicolumn{4}{c}{ Phases } \\
\cline { 2 - 5 } & $\mathbf{I}$ & II & \multicolumn{2}{c}{ III } \\
\hline OLR (gVS/L.d) & 3.0 & 3.0 & 3.0 & 2.0 \\
Operating time (days) & $63-98$ & $99-259$ & $260-287$ & $289-311$ \\
$\mathrm{R} 1-\mathrm{CH}_{4}$ yield (mL/gVS) & $170 \pm 19$ & $169 \pm 25$ & $137 \pm 22$ & $164 \pm 25$ \\
$\mathrm{R} 2-\mathrm{CH}_{4}$ yield (mL/gVS) & $182 \pm 14$ & $189 \pm 24$ & $197 \pm 20$ & $238 \pm 22$ \\
Increment $\mathrm{CH}$ yield (\%) & $8 *$ & $12 *$ & $44 *$ & $45 *$ \\
\hline
\end{tabular}

* Significant difference between R1 and R2

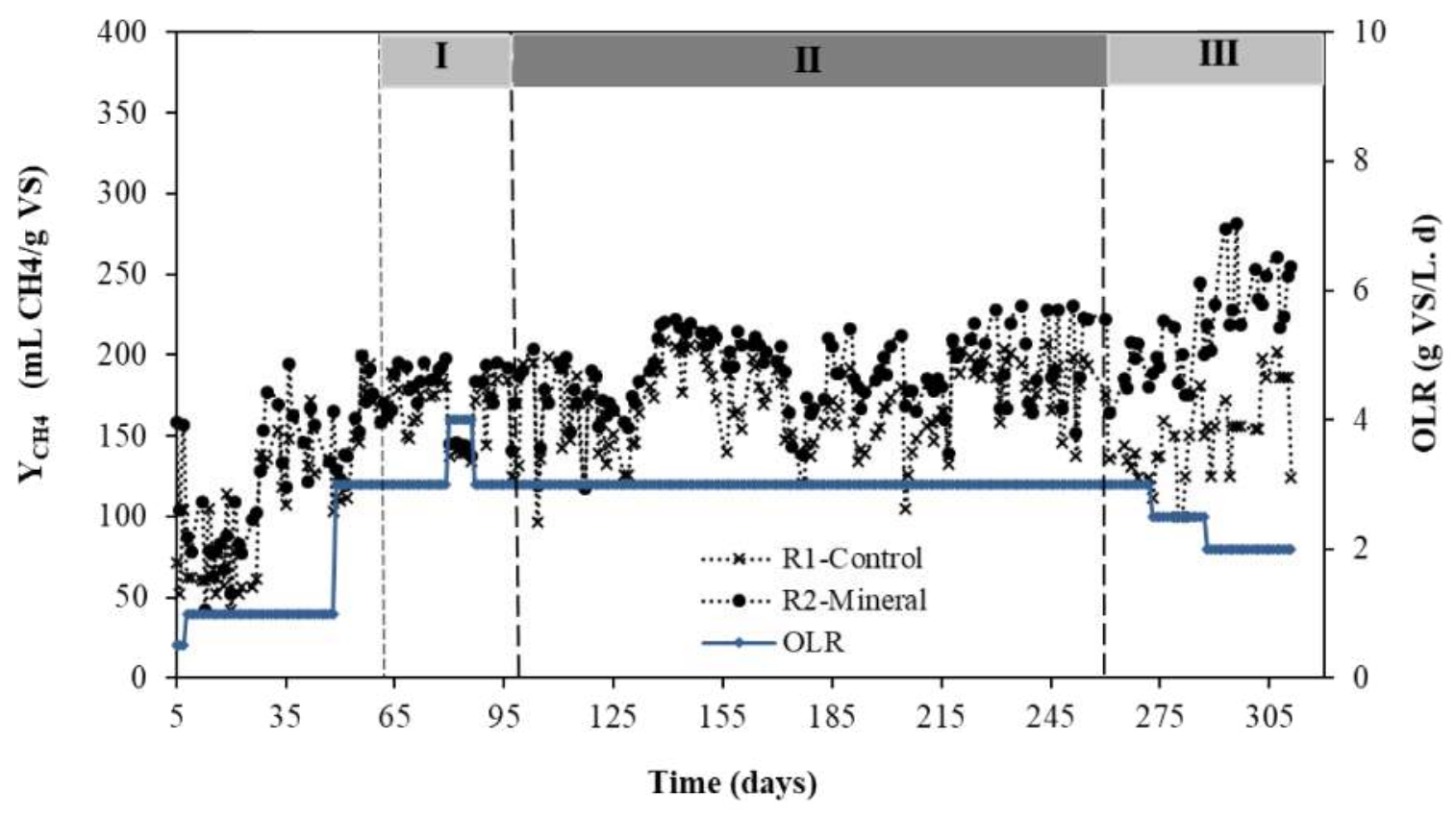

Figure 1 Methane yields obtained during the anaerobic mono-digestion of rice straw with and without mineral addition. Dashed lines represent the changes in dosing strategy in R2

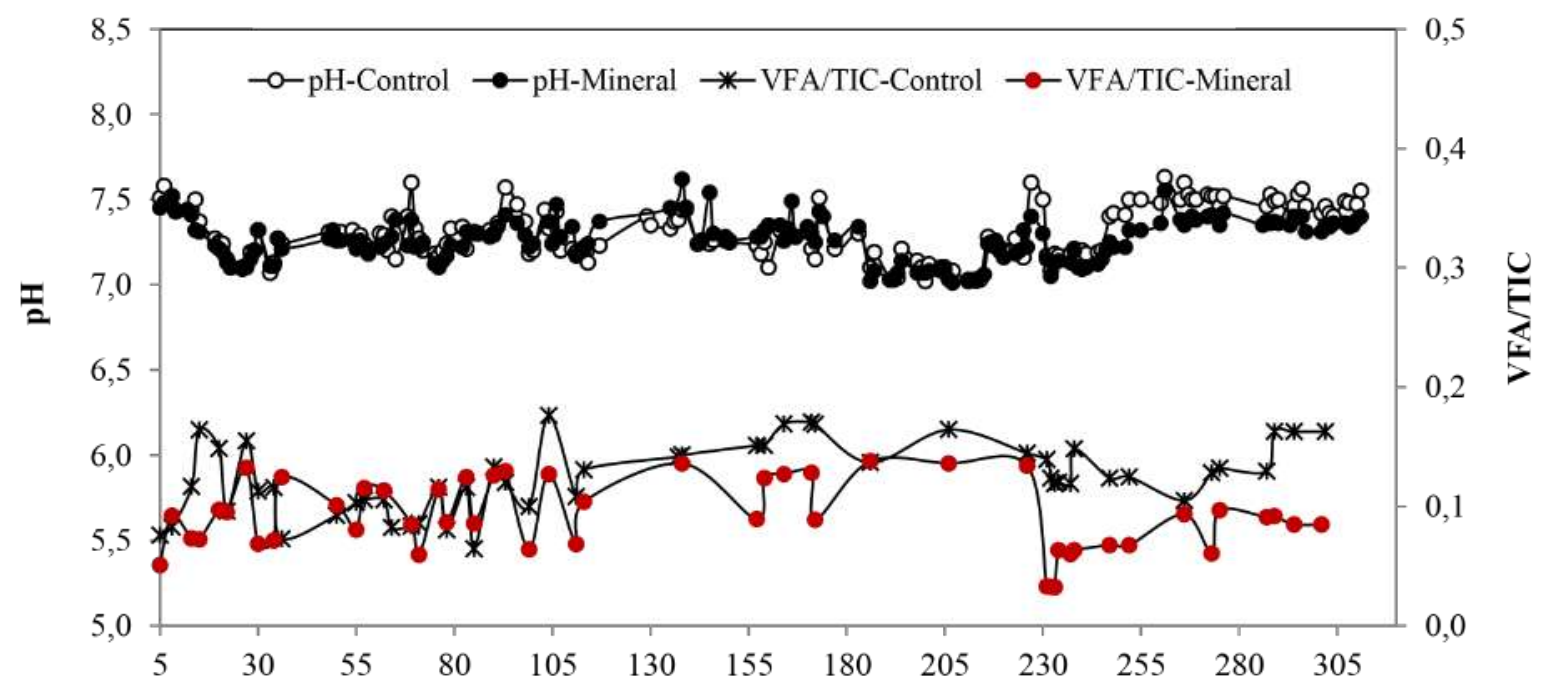

Time (days)

Figure $2 \mathrm{pH}$ and VFA/TIC ratio values obtained from biodegradation of rice straw with and without mineral addition 
Table 4 Metal concentrations* for R1 and R2 in the SE-fractions achieved after 260, 294 and 308 days of digestion

\begin{tabular}{|c|c|c|c|c|c|c|c|}
\hline \multirow{2}{*}{ Day } & \multirow{2}{*}{ Fraction } & \multicolumn{3}{|c|}{ R1 (mg/g TS) } & \multicolumn{3}{|c|}{ R2 (mg/g TS) } \\
\hline & & $\mathrm{Fe}$ & $\mathrm{Ni}$ & Co & Fe & $\mathrm{Ni}$ & Co \\
\hline \multirow{6}{*}{260} & Exchangeable & 0.098 & 0.00 & 0.002 & 0.21 & 0.00 & 0.009 \\
\hline & Carbona & 0.119 & 0.00 & 0.004 & 0.13 & 0.00 & 0.009 \\
\hline & Oxidizable & 013 & 0.00 & 0.014 & 0.06 & 0.00 & 0.000 \\
\hline & Reside & 0.135 & 0.00 & 0.005 & 0.12 & 0.00 & 0.012 \\
\hline & $\sum S E$ & 0.365 & 0.00 & 0.025 & 0.51 & 0.00 & 0.031 \\
\hline & Recovery (\%) & 75 & 0 & 78 & 81 & 0 & 83 \\
\hline \multirow{6}{*}{294} & Exchangeable & 0.000 & 0.00 & 0.015 & 0.38 & 0.015 & 0.051 \\
\hline & & 0.155 & 0.00 & 0.018 & 1.66 & 0.103 & 0.145 \\
\hline & Oxidizable & 0.041 & 0.00 & 0.010 & 0.29 & 0.009 & 0.075 \\
\hline & Residual & 0.061 & 0.00 & 0.009 & 0.69 & 0.007 & 0.016 \\
\hline & $\sum S E$ & 0.257 & 0.00 & 0.052 & 3.02 & 0.130 & 0.288 \\
\hline & Recovery (\%) & 82 & 0 & 82 & 92 & 90 & 93 \\
\hline \multirow{6}{*}{308} & Exchangeable & 0.000 & 0.00 & 0.000 & 0.36 & 0.039 & 0.094 \\
\hline & Carbona & 0.124 & 0.00 & 0.000 & 2.27 & 0.134 & 0.157 \\
\hline & Oxidizab & 0.082 & 0.00 & 0.004 & 0.12 & 0.012 & 0.054 \\
\hline & Residual & 0.129 & 0.00 & 0.005 & 0.85 & 0.010 & 0.004 \\
\hline & $\sum S E$ & 0.335 & 0.00 & 0.009 & 3.60 & 0.190 & 0.310 \\
\hline & Recovery (\%) & 81 & 0 & 79 & 85 & 98 & 96 \\
\hline
\end{tabular}

*Mean value \pm standard deviation $(n=3)$.

$\sum$ SE: Sum of the elements extracted after each SE step.

Values below the limit of detection indicated as 0.00 .

on methane yield after trace elements addition in form of inorganic salts, during mono-digestion of lignocellulosic residues [2, 21, 23], with increasing in the methane yield ranged from $12-35 \%$. The methane yield values obtained in this study with mineral supply are comparable to the reached using inorganic salts, which is profitable as technological alternative. Based on these results, it can be suggested that $1 \mathrm{~g} / \mathrm{L}$ of mineral once a week provides the requirements of trace elements for microbial uptake and improve the stability of anaerobic process.

\subsection{Effects of $\mathrm{Fe}$, Ni and Co speciation and bioavailability}

Table 4 displays the results of sequential extraction at 260 (day 0), 294 and 308 days of operation. Fe, Ni and $\mathrm{Co}$ concentrations, calculated as the sum of the SE-fractions, were similar to concentrations measured with the acid digestion method.

Recovery from the sum of the SE-fractions was included between SD of $\pm 20 \%$, except for Fe $(75 \%)$ and Co $(78 \%$ and $79 \%$ ) for R1, assuring the validity of the results (Table 4). Similar values are reported in the literature with the same sequential extraction scheme $[28,29]$.

$\mathrm{Fe}, \mathrm{Ni}$ and $\mathrm{Co}$ fractions exhibited different changes during the process. In the reactor mineral-limited (R1), the speciation of these metals proves a low bioavailability with a trend to decrease during the experiment (Figure 3). In the case of $\mathrm{Ni}$, the concentrations were below the limit of detection during the sequential extraction. It should be kept in mind that $\mathrm{Ni}$-concentration in the inoculum at the beginning of the study was very low, and it was also not detected in the substrate. Therefore, the Ni depletion in R1 was assumed during long-term anaerobic mono-digestion of rice straw.

In R1, it was also observed that Fe mainly was as carbonate fraction (43\%), bioavailable for metals uptake by microorganisms, and residual fraction $(33 \%)$ considered unavailable for cell uptake. The exchangeable and oxidizable fractions of $\mathrm{Fe}$ remained almost negligible regarding the other fractions (Table 4). In addition, the $41 \%$ of Co was associated to the oxidizable fraction, with a trend to diminish until the end of experiment. On day 308 , the exchangeable and carbonates fractions of Co were also not detected in R1, which indicate a change in the speciation of Co toward the fractions less bioavailable (oxidizable and residual), causing a metal bioavailability greatly decreased (Figure 3). Similar findings were described by [4], where the Co (39.1\%) mainly existed as oxidizable fraction during food waste biodegradation.

Metal speciation results from this reactor confirmed that, the absence of trace elements for microorganism at the end of the study, causes a negative effect on the methane production. 


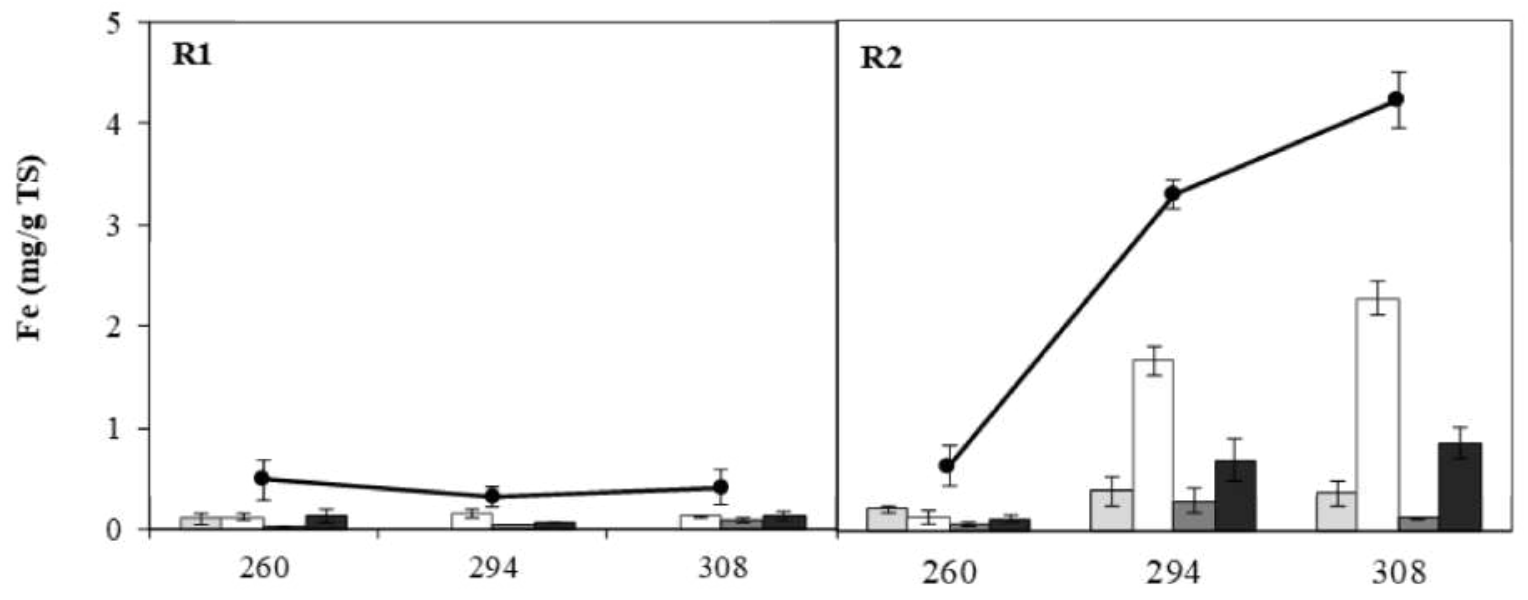

(a)

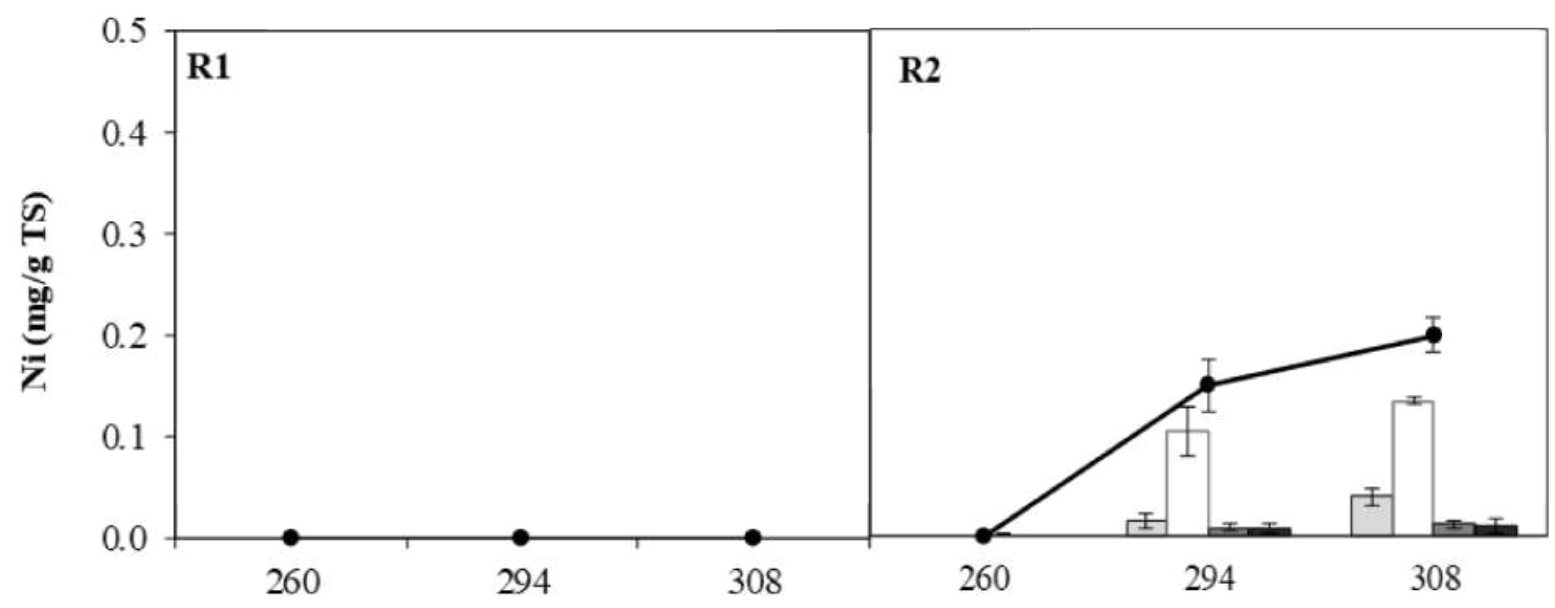

(b)

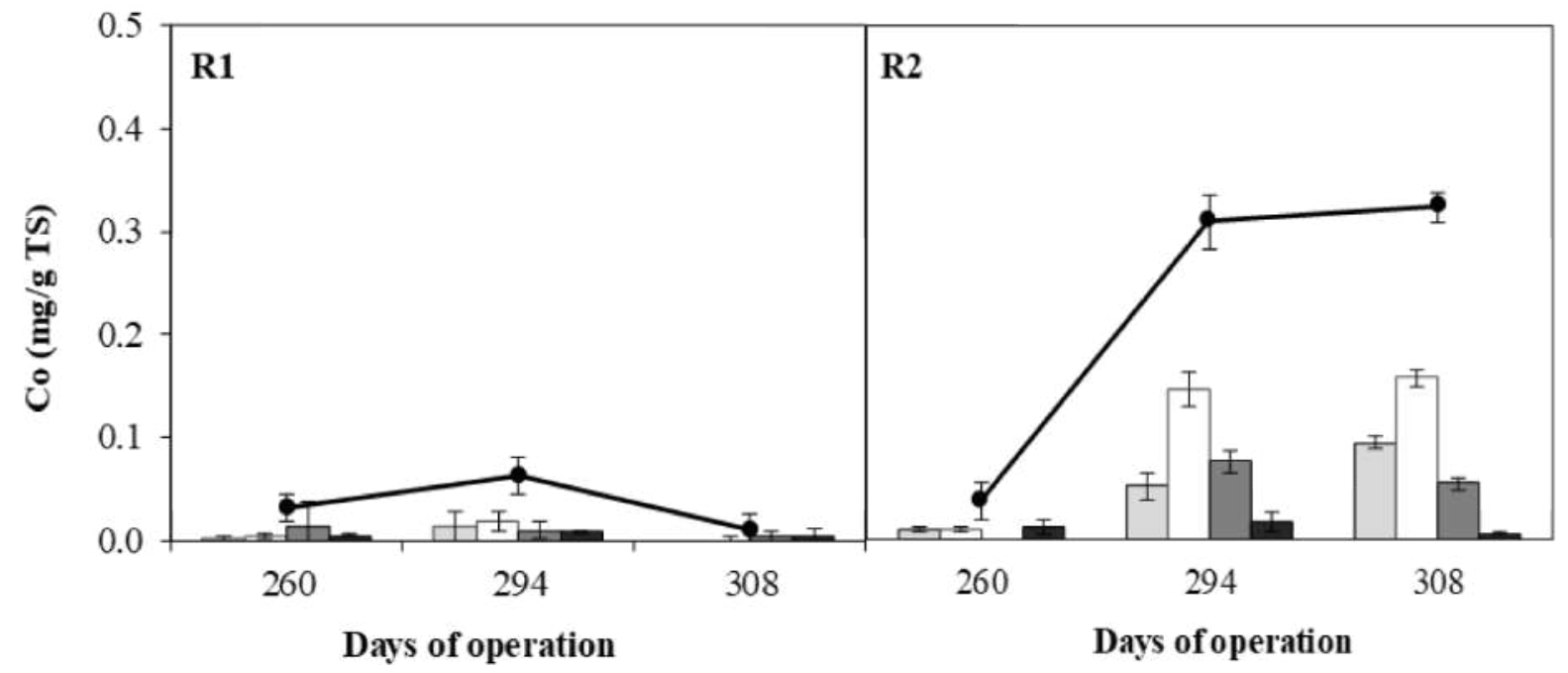

(c)

Figure 3 Sequential extraction of (A) Fe, (B) Ni and (C) Co from control reactor- R1 and mineral addition- R2. $\square$ Exchangeable; $\square$ Carbonate; $\square$ Oxidizable; Residual; - Total. Standard deviations are given as error bars 
However, the mineral supply in R2 increased the total concentrations of $\mathrm{Fe}, \mathrm{Ni}$ and $\mathrm{Co}$ respect to the initial state (Day 260). Similarly, the dominant speciation of Fe, Ni and Co were in the most bioavailable fractions for microbial uptake (exchangeable and carbonate), corresponding to $70 \%, 88 \%$ and $75 \%$, respectively, with a trend of increase with time (Figure 3, Table 4).

It is possible to observe that the speciation of $\mathrm{Fe}, \mathrm{Ni}$ and $\mathrm{Co}_{0}$ in the most bioavailable fractions lexchangeable and carbonate) correlated well with the highest methane yield reached in each reactor. The reactor $\mathrm{R} 1$ had the lowest percentage of these fractions, i.e. Fe (52\%), Ni (0.0) and Co $(30 \%)$, and the lowest methane yield. While, R2 clearly showed the stimulative effect on methane yield with the highest percentages of most bioavailable fractions, i.e. Fe $(70 \%), \mathrm{Ni}(88 \%)$ and $\mathrm{Co}(75 \%)$. The results are in agreement with the reported by [30], who revealed the relation between metal speciation and methane yield and concluded that the metals binding to more bioavailable fractions led to a higher microbial uptake.

The potential bioavailability of $\mathrm{Fe}, \mathrm{Ni}$ and $\mathrm{Co}$ is evaluated from the bonding form distribution, considering that the fractions with high solubility are more available for microorganisms. Potential bioavailability was different for each metal in both reactors. R1 showed a bioavailability ( $\mathrm{Fe} \gg \mathrm{Co}$ ), while in $\mathrm{R} 2$ the potential bioavailability $(\mathrm{Ni} \gg \mathrm{Co}$ $\mathrm{Fe}$ ) was higher in comparison to R1. When taking only the most bioavailable fractions into account lexchangeable and carbonate), Ni has a much higher potential bioavailability compared to the other metals in R2. Above all, the trace elements have a much higher potential bioavailability compared to the other metals in R1. Therefore, the high metals availability was able to maintain the metals uptake by microorganisms. Findings confirmed that the mineral dosage strategy in R2 had a stimulating effect on methane yield during rice straw mon-digestion.

\section{Conclusions}

The anaerobic biodegradation of rice straw was limited due to the deficiency of trace elements during a long-time operation decreasing the methane yield and provoking process instability. The speciation of $\mathrm{Fe}, \mathrm{Ni}$ and $\mathrm{Co}$ supply at $1 \mathrm{~g} \mathrm{~L}^{-1}$ by a mineral source, proved to have a stimulating effect on the process when it was applied once a week. Certainly, it was an effective strategy for enhancement of long-term anaerobic digestion of rice straw, with a remarkable stimulating effect on methane yield respect to the reactor without mineral. Exchangeable and carbonates fractions dominated the bonding form of $\mathrm{Fe}, \mathrm{Ni}$ and $\mathrm{Co}$ during rice straw biodegradation with mineral addition and hence a high metals uptake by methanogens that strengthened the stimulating effects on the methane yield.

\section{Declaration of competing interest}

We declare that we have no significant competing interests including financial or non-financial, professional, or personal interests interfering with the full and objective presentation of the work described in this manuscript.

\section{Acknowledments}

This research was supported by the Universidad Tecnológica de La Habana “José A. Echeverría” (CUJAE).

\section{References}

[1] C. Sawatdeenarunat, K. Surendra, D. Takara, H. Oechsner, and S. Khanal, "Anaerobic digestion of lignocellulosic biomass: Challenges and opportunities," Bioresource Technology, vol. 178, february 2015. [Online]. Available: https://doi.org/10.1016/ j.biortech.2014.09.103

[2] I. Nges, B. Wang, Z. Cui, and J. Liu, “Digestate liquor recycle in minimal nutrients-supplemented anaerobic digestion of wheat straw," Biochemical Engineering Journal, vol. 94, february 152015. [Online]. Available: https://doi.org/10.1016/j.bej.2014.11.023

[3] T. Schmidt, M. Nelles, F. Scholwin, and J. Pröter, "Trace element supplementation in the biogas production from wheat stillage - optimization of metal dosing," Bioresource Technology, vol. 168, september 2014. [Online]. Available: https://doi.org/10.1016/j. biortech.2014.02.124

[4] W. Zhang, L. Zhang, and A. Li, "Enhanced anaerobic digestion of food waste by trace metal elements supplementation and reduced metals dosage by green chelating agent [S, S]-EDDS via improving metals bioavailability," Water Research, vol. 84, november 12015. [Online]. Available: https://doi.org/10.1016/j.watres.2015.07.010

[5] F. Fermoso, J. Bartacek, S. Jansen, and P. Lens, "Metal supplementation to uasb bioreactors: from cell-metal interactions to full-scale application," Science of The Total Environment, vol. 407, june 1 2009. [Online]. Available: https://doi.org/10.1016/j.scitotenv. 2008.10.043

[6] Z. Lei, J. Chen, Z. Zhang, and N. Sugiura, "Methane production from rice straw with acclimated anaerobic sludge: Effect of phosphate supplementation," Bioresource Technology, vol. 101, no. 12, june 2010. [Online]. Available: https://doi.org/10.1016/j.biortech.2010. 01.083

[7] K. Khatri and et al, "Synergistic effect of alkaline pretreatment and fe dosing on batch anaerobic digestion of maize straw," Applied Energy, vol. 158, november 15 2015. [Online]. Available: https://doi.org/10.1016/j.apenergy.2015.08.045

[8] W. Zhong and et al, "Effect of biological pretreatments in enhancing corn straw biogas production," Bioresource Technology, vol. 102, no. 24, december 2011. [Online]. Available: https://doi.org/10.1016/ j.biortech.2011.09.077

[9] K. Pilarski and et al, "The impact of extrusion on the biogas and biomethane yield of plant substrates," Journal of Ecological Engineering, vol. 17, no. 4, september 2016. [Online]. Available: https://doi.org/10.12911/22998993/64563

[10] B. Evranos and B. Demirel, "The impact of $\mathrm{Ni}, \mathrm{Co}$ and Mo supplementation on methane yield from anaerobic mono-digestion of maize silage," enviromental technology, vol. 36, no. 9-12, may-june 2016. [Online]. Available: https://doi.org/10.1080/09593330.2014. 997297

[11] H. Pobeheim, B. Munk, H.Lindorfer, and G. Guebitz, "Impact of nickel and cobalt on biogas production and process stability during semi-continuous anaerobic fermentation of a model substrate for 
maize silage," Water Research, vol. 45, no. 2, january 2011. [Online]. Available: https://doi.org/10.1016/j.watres.2010.09.001

[12] A. Suárez, K. Nielsen, S. Köhler, D. MerenciollI, and I. Reyes, "Enhancement of anaerobic digestion of microcrystalline cellulose (mcc) using natural micronutrient sources," Brazilian Journal of Chemical Engineering, vol. 31, no. 2, april/june 2014. [Online]. Available: http://dx.doi.org/10.1590/0104-6632.20140312s00002689

[13] A. González and et al, "Effect of natural mineral on methane production and process stability during semi-continuous mono-digestion of maize straw," Applied Biochemistry and Biotechnology, vol. 178, no. 8, april 2016. [Online]. Available: http://dx.doi.org/10.1007/s12010-015-1965-8

[14] Fermentation of organic materials - Characterization of the substrate, sampling, collection of material data, fermentation tests, VDI, 2016.

[15] A. González and et al, "Bioavailability and dosing strategies of mineral in anaerobic monoDdigestion of maize straw," Engineering in Life Sciences, vol. 18, no. 8, august 2018. [Online]. Available: https://doi.org/10.1002/elsc.201700018

[16] M. Begoña, E. van, M. Zandvoorta, J. Izab, and P. Lens, "Effect of cobalt sorption on metal fractionation in anaerobic granular sludge," Journal of Environmental Quality Abstract, vol. 33, no. 4, july-august 2004. [Online]. Available: https://doi.org/10.2134/jeq2004.1256

[17] A. Tessier, P. Campbell, and M. Bisson, "Sequential extraction procedure for the speciation of particulate trace metals," Analytical Chemistry, vol. 51, no. 7, june 1 1979. [Online]. Available: https: //doi.org/10.1021/ac50043a017

[18] L. H. and et al, "The valuation of malnutrition in the mono-digestion of maize silage by anaerobic batch tests," Water Science and Technology, vol. 58, no. 7, october 2008. [Online]. Available: https://doi.org/10.2166/wst.2008.491

[19] C. L. and et al, "Improving biomethane production and mass bioconversion of corn stover anaerobic digestion by adding naoh pretreatment and trace elements," Journal of Biomedicine and Biotechnology, vol. 2015, no. 13, july 2015. [Online]. Available: https://doi.org/10.1155/2015/125241

[20] M. Ortner, M. Ramedera, L. Rachbauer, G. Bochmann, and W. Fuchs, "Bioavailability of essential trace elements and their impact on anaerobic digestion of slaughterhouse waste," Biochemical Engineering Journal, vol. 99, july 15 2015. [Online]. Available: https://doi.org/10.1016/j.bej.2015.03.021

[21] J. Moestedt and et al, "Effects of trace element addition on process stability during anaerobic co-digestion of ofmsw and slaughterhouse waste," Waste Management, vol. 47, no. Part A, january 2016. [Online]. Available: https://doi.org/10.1016/j.wasman. 2015.03.007

[22] B. Demirel and P.Scherer, "Trace element requirements of agricultural biogas digesters during biological conversion of renewable biomass to methane," Biomass and Bioenergy, vol. 35, no. 3, march 2011. [Online]. Available: https: //doi.org/10.1016/j.biombioe.2010.12.022

[23] W. Mussoline, G. Espositoa, P. Lens, A. Spagnic, and A. Giordano, "Enhanced methane production from rice straw co-digested with anaerobic sludge from pulp and paper mill treatment process," Bioresource Technology, vol. 148, november 2013. [Online]. Available: https://doi.org/10.1016/j.biortech.2013.08.107

[24] S. Menardo, V. Cacciatore, and P. Balsari, "Batch and continuous biogas production arising from feed varying in rice straw volumes following pre-treatment with extrusion," Bioresource Technology, vol. 180, march 2015. [Online]. Available: http://dx.doi.org/10.1016/ j.biortech.2014.12.104

[25] R. Zhao and et al, "Methane production from rice straw pretreated by a mixture of acetic-propionic acid," Bioresource Technology, vol. 101, no. 3, february 2003. [Online]. Available: http://dx.doi.org/10. 1016/j.biortech.2009.09.020

[26] L. M. Contreras, H. Schelle, C. Sebrango, and I. Pereda, "Methane potential and biodegradability of rice straw, rice husk and rice residues from the drying process," Water Science and Technology, vol. 65, no. 6, march 2012. [Online]. Available: http://dx.doi.org/10. 2166/wst.2012.951

[27] V. Facchin and et al, "Effect of trace element supplementation on the mesophilic anaerobic digestion of foodwaste in batch trials: The influence of inoculums origin," Biochemistry Engineering Journal, vol. 70, january 15 2013. [Online]. Available: http: //dx.doi.org/10.1016/j.bej.2012.10.004

[28] M. H. Zandvoort and E. D. Van Hullebusch and F. Fermoso and P. N. Lens, "Trace metals in anaerobic granular sludge reactors: Bioavailability and dosing strategies," Engineering Life in Science, vol. 6, no. 3, june 2006. [Online]. Available: http: //dx.doi.org/10.1002/elsc.200620129

[29] A. Van der Veen and F. Fermoso and P. N. Lens, "Bonding form analysis of metals and sulphur fractionation in methanol-grown anaerobic granular sludge," Engineering in Life Sciences, vol. 7, no. 5, october 2007. [Online]. Available: http://dx.doi.org/10.1002/ elsc. 200720208

[30] J. Gustavsso, S. Yekta, A. Karlsson, U. Skyllberg, and B. Svensson, "Potential bioavailability and chemical forms of $\mathrm{Co}$ and $\mathrm{Ni}$ in the biogas process - An evaluation based on sequential and acid volatile sulfide extractions," Engineering in Life Sciences, vol. 13, no. 6, november 2013. [Online]. Available: http://dx.doi.org/10.1002/elsc. 201200162 